Global Conferences Series:

Social Sciences, Education and Humanities (GCSSSEH), Volume 3, 2019

The $1^{\text {st }}$ International Conference on Education, Social Sciences and Humanities

DOI: https://doi.org/10.326/hum0222

\title{
Anthropometry and Physical Factors for Determining Skills of Drive in Squash Game
}

\section{Irvan}

Universitas Negeri Makassar

凶irvansir@unm.ac.id

\begin{abstract}
The purpose of this study was: To determine the anthropometric factors that determine blow drive skills in squash games and to determine the physical factors that determine the drive blow skills. The anthropometric factor that determines blow drive skills is body weight with a percentage of roles to a factor of $85.5 \%$. height with a percentage of roles to a factor of $85.4 \%$, and the length of the legs with the percentage of roles to a factor of $37.5 \%$, and the physical factor that determines the skill of the drive is the grip strength of $67 \%$, flexibility of $33.5 \%$, coordination ankles by $39.5 \%$, leg muscle power by $75 \%$, agility by $78.3 \%$ at $97 \%$, and cardiovascular endurance by $71.5 \%$. Anthropometry and physical factors (latent variables $\xi 1$ ) that determine blow drive skills can be measured by weight indicator variables $(0.888 ; 0.855)$, height $(0.877 ; 0.854)$, leg length $(0.451 ; 0.375)$, grip strength $(0.719 ; 0.670)$, flexibility $(0.432 ; 0.335)$, hand eye coordination $(0.546 ; 0.539)$, limb muscle power $(0.765 ; 0.750)$, agility $(0.789 ; 0.783)$, speed $(0.8158 ; 0.816)$ and cardiovascular endurance $(0.754 ; 0.715)$ will bring FIK UNM students to improve theirblow drive skills in the game of squash.
\end{abstract}

Keywords: Anthropometry, Physical, Skill drive

\section{Introduction}

The squash sports branch is a game sport played by two people using a racket and a small ball inside a limited room and or surrounded by a wall. The goal of this game is a player trying to hit the ball into the front wall in such a way that the opponent can not and it is difficult to return the ball from the opponent. The difference is if the tennis reflects from the one ball hitter in front of the other bat, while in the ball squash sport is reflected by a way to hit the wall. The reflection of this wall will be accepted by the other opponent standing next to him. One of the guidance / training container for the sport is at the level or level of school and campus. Since athlete squads for squash sports in South Sulawesi rely only on the Faculty of Sport Science, this is why one of the achievement factors of squash sports in South Sulawesi has not experienced significant growth.

The increase of squash achievement in South Sulawesi can be developed by increasing the interest or interest of students to program the squash courses, as the elective course which later can be mastered as the preferred sport branch not only serve as complement to SKS fulfillment in the 
completion of study, for achievement, especially in an effort to increase squash performance in South Sulawesi.

To improve the achievements of the sports squash branch, students must master basic engineering skills of squash sports. Some of these basic techniques are drive blows, service, volleyball, boast, lob, drop shot and so on. Mastery of these basic engineering skills should be trained in accordance with the training program by providing a continuous form of training method.

One of the greatest indications for improving sports achievement is physical formation and the anthropometry of athletes. Formation of physical elements, to create squash players in accordance with the demands of squash match criteria, certainly can not be separated from the nursery process is expected to produce superior athlete seeds, because anthropometry and physical factors will be very decisive in the process of training toward achievement. The selection of athletes to pursue the squash sports is inseparable from the body shape (anthropometry). The ideal body shape in accordance with the learning sports is one of the conditions that can affect the achievement of sports achievement. Mochamad Sajoto (1995: 11) states "One aspect to achievement in sport is the biological aspect which includes the structure and posture of body height and length of legs, large size, width and weight, and somatotype (body shape)".

To improve the achievements of the sports squash branch, students must master basic engineering skills of squash sports. Some of these basic techniques are drive blows, service, volleyball, boast, lob, drop shot and so on. Mastery of these basic engineering skills should be trained in accordance with the training program by providing a continuous form of training method.

Mastery of basic engineering skills a drive blow in a squash play must be owned by a player. By mastering this blow the player can point the ball into an empty corner of the field where the opponent is difficult to reach the ball. One of the keys to getting a number is to place and direct the reflection of the ball from the front wall to fall in the corner between the side wall and the floor, so the ball does not bounce anymore and can not be beaten by the opponent .. Many training methods have been applied to develop the technique of the drive blow , but still not paying attention to the right way and can produce a good drive blow.

Therefore based on the above assumptions required an answer to the problems that have been described previously, so there must be a deeper study through research. Thus the researchers wanted to know the skills of the drive blow in the game Student FIK UNM Makassar squash associated with anthropometric and physical dominant factors.

The aim of this study; 1 ) To determine the anthropometry factors that determine the achievement of forehand forehand skills in the game Student FIK UNM Makassar squash, 2) To determine the physical factors that determine the achievement of forehand forehand skills in the game Student FIK UNM Makassar squash.

\section{Literature Review}

\section{History of Squash Games}

Squash sport actually existed in the 19th century, in the Fleet Prison area of London (http://ggoblog.blogspot.com/2013/11/ history-and-how-play-squash.html). According to Hanlon (2009: 226) the popularity of squash has spread to various countries and is played worldwide by 15 million people, with squash courts in almost every country. Recently the game has increased in popularity in South America, Eastern Europe, and the United States. Although born and raised in England, it was the United States who first established the squash association in 1907 under the name of the United States Squash Racquets Association. In fact, in his native England the squash was originally a branch of tennis court. The new Squash stood alone in England in 1928 under the name Squash Rackets 
Association. Since then the UK has always held a tournament squash with the name of the British Open. It was the British who brought the sport to all corners of the world, especially at the time of colonialism. Not surprisingly, if the British colonies joined in commonwealth countries such as Australia, Pakistan, Malaysia, Singapore first to squash than Indonesia.In Indonesia itself, the sport of squash is already known since World War II ended, precisely in 1948.

British troops who first built a squash squad in Indonesia located at Embong Sawo Surabaya. But at that time, only officers of the rank of general were allowed to play the sport. Even until 1978 only foreigners played squash sports in Indonesia. Yet at that time squash field is an absolute requirement for star hotels in Indonesia. In 1979, the red thread of the history of the development of squash began to be inscribed by a native son of Indonesia named Bambang Gatot Subroto. At that time Bambang who often watched the squash game because he worked at a five-star hotel in Jakarta was offered steeped squash in Pakistan. The opportunity of gold is not wasted by Bambang. Though not yet as good as the world-famous Pakistani squash legend known as the 'Khan Dynasty', such as Hashim Khan, Roshan Khan, Azam Khan, Mohibullah Khan, Jahangir Khan and Jansher Khan who alternately took turns to become British Open champions from 1951 to 1994, Bambang has been able to defeat Foreign Citizens especially from Europe who stay at his place of work. Whereas before he was always made monthly-monthly by the tourists.

\section{Anthropometric and physical factors}

Anthropometric factors in squash games

Anthropometry is the study of the measurement of the human body in terms of the dimensions of bone, muscle, and adipose (fat) tissue. The word "anthropometry" comes from the Greek word "anthropo" which means man and "metron" which means size. The field of anthropometry includes various measurements of the human body. Weight, height, posture, stretch length, skin fold thickness, circumference (head, chest, waist, leg, etc.), length of limb (arm, leg). Gallahue and Ozmun (1998: 189) say that the development of anthropometric size of the body develops according to the period of individual development. The development of the size of these body parts is influenced by developmental factors such as genetic factors, environment and physical movement activities performed. The development of body size and its parts continues throughout the growth period with varying degrees of development in proportion and speed. The growth of the baby's size progresses very quickly, then proportionally decreases in childhood and then experiences explosive growth during adolescence. The difference in the rate of growth leads to variations in the shape and type of a person's body.

Anthropometry involves measuring external body parts. There are two types of anthropometric measurements: body and somatotropy dimensions. Somatotropy is the process of measuring and describing the body's confirmation morphologically. In general can be described 3 forms and the composition of the human body: (1) endomorph, (2) mesomorph, and (3) ectomorph. Every human body is made up of the various levels of the three. The first classification (somatotype) is determined by the sum of each component in a single phase. The ideal body shape according to the sports branch studied is one of the conditions that can affect the achievement of sports achievement.

Physical Factor in squash game

Harsono, (1988: 57) Physical condition is a unified whole of the components that can not be separated just like that, both the increase and maintainers. This means that in the effort to improve the physical condition, all components must be developed. Physical quality is very influential on the achievement of an athlete to achieve achievement because techniques, tactics and mental will be developed further if it has good physical quality. The goal of physical exercise is to improve the quality of the muscle system and the quality of the energy system that is to train the elements of 
motion or biomotor, (Djoko Pekik I, 2002: 65). Good physical conditions have advantages, including athletes able and easy to learn skills that are relatively difficult, not easily tired during training and games, training programs can be completed without having many obstacles and can complete the heavy workout. Physical condition is needed by an athlete, because without the support of the physical condition of the prime then the achievement of peak performance will experience many obstacles, and impossible to achieve high. Physical fitness can be defined as the ability to function effectively throughout the day during activity, usually when we do other activities, still have enough energy left to handle additional pressure or emergencies that may arise.

The status of a person's physical condition is known by means of judgment in the form of a measurement test. This test can be done in the laboratory or in the field. Although tests conducted in the laboratory require expensive tools, they should be done so that the results of the assessment are objective. Physical conditions can reach an optimal point if the exercise starts from an early age and is done continuously. Because to develop the physical condition is not an easy job, must have a physical trainer who has certain qualifications so as to foster physical development of athletes thoroughly without causing effects in the future.

Physical condition factors that match the characteristics of the sport squash are as follows;

Flexibility

Bompa (1994: 317) is the capacity to make the movement with the widest range. Flexibility contains the understanding, namely the extent of motion of one joint or some joints. There are two kinds of flexibility, namely (1) static flexibility, and (2) dynamic flexibility. Static flexibility is determined by the measure of the extent of motion of one joint or several joints. An example is for measuring the extent of spinal cord motion by means of sit and reach, front splits, and slide splits.

Endurance

Endurance is the ability of the body or parts of the body in doing work within a certain time that is influenced by the working ability of the work system kardiorespiratori. Endurance is often defined as the ability of working muscles to work for a long time, but experts classify durability based on length of work into three groups, namely durability of long, medium and short.

Speed

Speed is one component of the physical condition required in every sport. Any sport activity that is game, race, or game always requires a component of the physical condition of speed. For that speed is one element of basic physical conditions that must be trained in an effort to support the achievement of athlete Speed is a very essential physical component in various sports, because the speed is included in the elements of basic physical conditions in addition to strength and durability endurance).

Power of arm muscles

Bompa (1999: 61) also describes briefly about the power of explosive or power, according to the explosive power is the ability of muscles to expel maximum power in a very short time. The formula used in explosive power is: power $/$ explosive power $=$ work $/$ time $=$ power $\times$ mileage. Power is divided into 2 (two), namely:

1. Explosive power; This strength is used to overcome the lower resistance, but with maximum explosive power acceleration. Power is often used to perform one motion or one repeat (long jump, throw discs, etc.). 
2. Rapid motion force; this movement is done against the resistance with acceleration below the maximum, this type is used to perform repetitive movements, such as running, pedaling, etc.

Coordination of the ankle

Squash skills are heavily influenced by both physical and technical skills. One of the physical components that a squash athlete must have in a roving movement is coordination. According to Harsono (2001: 39) coordination is the ability to integrate various movements into one or more special motion patterns.

Hypothesis

Based on the preparation of the theoretical framework and framework bepikir mentioned above, the research hypothesis can be formulated as follows; 1) Anthropometry factors of height, weight, and leg length determine the skills of a drive blow in a game of Student FIK UNM Makassar squash; 2) Physical factors of grip strength, flexibility, endurance, speed, arm muscle power, leg muscle power, hand eye coordination and cardiovascular endurance determine the driving skill of the student FIK UNM Makassar squash game.

\section{Method}

Research Methods

Methods of research relate Research methods The type of research used in this research is correlational research with the design of confirmatory factor analysis is to confirm the relationship of indicator variable with latent variable that determines the skills of the drive blow. The collected data is further verified and tabulated to then be quantitatively processed by: a) Multivariate statistical factor analysis using SPSS computerized software so that it can be reduced to several factors only; $b$ ) Calculates the average donation value of each factor on the latent variable and the dependent variable; c) Describes the value and position of the average score of the dominant variable in the transformation of the importance-performance matrix. The research design can be seen in the following picture.

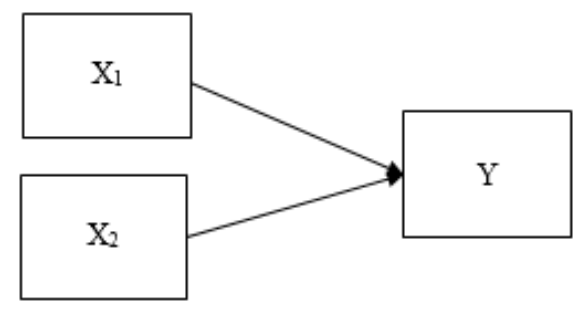

Figure. 1. Research of Design

\section{Research Sites}

This research was conducted at Squash Field of Banta-Bantaeng Campus Faculty of Sport Science Universitas Negeri Makassar from month from March until May 2017.

\section{Data Collection Technique}

The execution of tests and measurements are as follows: 1) anthropometry such as a) augmenting a) height, b) body weight and 3) limb length, 2) for measurement of physical components such as a) gengaman power; b) balance; c) flexibility; d) hand eye coordination, e) vertical jump; e) agility; f) speed; cardiovascular endurance; 3) Drive blows that include three dimensions, namely; (a) initial position; (b) implementation of movement; and (c) the final position.

Data Analysis Technique 
The data collected through the test is still a rough data and then the data is tabulated for descriptive frequency test and simple correlation test and multiple correlation test using KMO-MSA (Kaiser-Meyer-Olkin and Measure of Sampling Adequacy); Anti-image correlation test; initial enginevalue; Communalities; Component matrix and Component score coefient matrix. The data is then analyzed by using statistical test with the help of SPSS program version 23.00.

\section{Result and Discussion}

The results of this study using a simple correlation test analysis and multiple correlation test to test; 1) Anthropometric factors of height, weight, and leg length determine the skills of a drive blow; 2) Physical factors of grip strength, flexibility, endurance, speed, muscle power of the arm, leg muscle power, hand eye coordination and cardiovascular endurance determine the driving skills of a punch in a squash game. Results Communalities Analysis of Anthropometric Factors and Physical Determinants Skill drives in a squash game. For more details can be seen in table 1 below: 
Table 1. Initial extraction

\begin{tabular}{lrr}
\hline Variable & Initial & Extraction \\
\hline Weight (X1) & 1.000 & .855 \\
Height (X2) & 1.000 & .854 \\
Leg Length (X3) & 1.000 & .375 \\
Grip Strength (X4) & 1.000 & .670 \\
Balance (X5) & 1.000 & .783 \\
Flexibility (X6) & 1.000 & .335 \\
Hand Eye Coordination (7) & 1.000 & .539 \\
Power of Leg Muscles (X8) & 1.000 & .750 \\
Agility / shuttle run (X9) & 1.000 & .783 \\
Speed (X10) & 1.000 & .816 \\
Endurance (X11) & 1.000 & .715 \\
\hline . Extraction Method: Principal Component Analysis & &
\end{tabular}

From the table 1 above can be seen the initial value and extraction value. The initial value reflects the role or contribution if variable penyususn factors individually form these factors, while the results comunalities for each variable is in the extraction column. The extraction value describes the percentage of roles or contributions of each dimension or sub-variable of the factor factors individually to the factor. It also means the number in the extraction column shows the percentage of rotated component matrix. From the table above it is known that the role of the largest dimension is the sub-variable weight, with a value of 0.855 or $85.5 \%$ and the smallest is the flexibility with a value of 0.335 or $33.5 \%$. Then to know the donation of each variable on each component, need to do the rotation process that produces Matrix component as above. Results of Rotated Component Matrixa Analysis of Anthropometric and Physical Factors The skill of a drive blow in a squash game in table 2 below;

Table 2. Rotated Component Matrix ${ }^{a}$

\begin{tabular}{|c|c|c|c|}
\hline & \multicolumn{3}{|c|}{ Component } \\
\hline & 1 & 2 & 3 \\
\hline Weight (X1) & -.018 & .918 & .110 \\
\hline Height (X2) & -.116 & .907 & .130 \\
\hline Leg Length (X3) & .336 & .447 & -.250 \\
\hline Grip Strength (X4) & .813 & -.085 & .029 \\
\hline Balance (X5) & .183 & -.126 & -.225 \\
\hline Flexibility (X6) & .507 & -.156 & .230 \\
\hline Hand Eye Coordination (7) & .549 & .460 & .159 \\
\hline Power of Leg Muscles (X8) & .836 & .135 & .180 \\
\hline Agility / shuttle run (X9) & -.845 & -.128 & -.228 \\
\hline Speed (X10) & -.137 & -.085 & -.889 \\
\hline Endurance (X11) & .397 & .106 & .739 \\
\hline
\end{tabular}


Based on Rotated Components Matrixa Results Analysis of anthropometric and physical factors determining the skill of a drive blow in a squash game, it turns out all the factor components have a value of $\geq 0.5$. This means that the dimensions of the anthropometric and physical factors consisting of variable grip strength, flexibility, hand eye coordination, leg muscle power, velocity, and cardiovascular endurance, are members of variable anthropometric and physical determinants of drive blows in squash games in FIK students UNM Makassar.

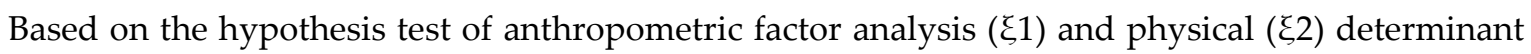
of drive blow skills in the above squash game, there is one anthropometric and physical variable that must be eliminated or excluded from dominant analysis factor or (H0 rejected) below 0.5 is the balance (0.397) while the anthropometric and physical factors that determine the skill of the drive blow in a squash game (H0 accepted) or that have a factor factor value of $\geq 0.5$

1. Weight with a factor component value that determines the drive's blow skills in a squash game of 0.855

2. Height with the value of a factor component that determines the drive's blow skills in a squash game of 0.854

3. The length of the limbs with the factor component values that determine the skill of the drive blow in a squash game of 0.375

4. The grip strength with a factor component value that determines the drive's blow skills in a squash game of 0.670

5. Balance with the value of a factor component that determines the skill of a drive blow in a squash game of 0.783

6. Flexibility with the value of a factor component that determines the skill of a drive blow in a squash game of 0.335

7. Hand eye coordination with the value of a factor component that determines the skill of a drive blow in a squash game of 0,395

8. Limb muscle power with the value of a factor component that determines the drive's blow skills in a squash game of 0.750

9. Agility with a factor component value that determines the drive's blow skills in a squash game of 0.783

10. Speed with component factor values that determine the skill of the drive blow in a squash game of 0.816

11. Cardiovascular endurance with a factor component value that determines the skill of a drive blow in a squash game of 0.715

The results of this study provide an illustration that the anthropometric and physical factors that determine the skill of a drive blow in a squash game are weight, height, leg length, grip strength, flexibility, hand eye coordination, leg muscle power, cardiovascular speed and endurance. From the results of data analysis and explanation above is known that there is one variable that has a small value or less dominant contribution that must be eliminated, namely balance. The balance is eliminated because the biomechanical balance does not have a close relationship with the skill, or in this case especially the field tennis. An acceptable explanation is the balance is the student capital of the driving skill in the student squad game FIK UNM Makassar in determining the drive blow in the squash game, the long-term practice process of the student balance of the driving skill of the student's FIK UNM Makassar squash game is relatively constant or constant, unlike flexibility or grip strength, which over time grows in both quality and function.

The result of factor analysis in this study was calculated using KMO and Bartlett's Test method with SPSS computerized statistical software supported by the theoretical base, from the explanation and analysis of data that has been done, it is obtained by anthropometry factor variable and physical 
determinant of hard drive skill in a squash game consisting of 8 (eight) indicator variables. The result of statistical test of factor analysis of all variables are as follows:

1. The dominant anthropometric factors in determining the driving skills of a squash game are weight, height and leg length while the physical factors that determine the driving skill of a squash game are grip strength, flexibility, hand eye coordination, leg muscle power, velocity, and power cardiovascular resistance. After data retrieval and further analysis of the data on the sample, it can be argued that the driving skill of the student squash game of the drive blow skills in a student squash game FIK UNM Makassar is formed or influenced by weight ( 0.888 and 0.855$)$, height (0.877 and 0.854), limb length (0.451 and 0.375), flexibility (0.432 and 0.335), hand eye coordination (0.546 and 0.539$)$, limb muscle power (0.765 and 0.750$)$, agility $(0.789$ and 0,783$)$, velocity (0.8158 and 0.816) and cardiovascular endurance (0.754 and 0.715). Because of the ten independent variables have a positive correlation value and are above $\geq 0.5$ based on the value of rotated component matrixa. So it can be concluded that the greater the rotated component matrix of these independent variables will increasingly benefit the student of the driving skill in the student squad game of FIK UNM Makassar in doing the drive blow in the squash game.

2. Anthropometric and physical factors that have a low or less dominant correlation value in determining the driving skill of a drive in a squash game are balance. This can be seen in the table of Anti Image matrices correlation 5.5, in the table there is one variable with MSA value below 0.50 is the balance (0.397), thus the factor must be eliminated or excluded from the further analysis test because it does not have sufficient value for further test.

\section{Conclusion}

The conclusions of the proposed research are based on the results of the data tabulated for the frequency descriptive test and simple correlation test and multiple correlation test using KMO-MSA (Kaiser-Meyer-Olkin and Measure of Sampling Adequacy); Anti-image correlation test; initial enginevalue; Communalities; Component matrix and Component score coefient matrix. Also presented suggestions for this research is used to improve the skills of the drive blow in the game of student squad FIK UNM Makassar.

Based on the results of the research and data analysis done, and referring to the discussion in the previous chapter, it turns out the proposed hypothesis can be accepted, so it can be concluded that anthropometric and physical factors (latent variables $\xi 1$ ) that determine the skill of a drive blow in a squash game can be measured by $(0.819$ and 0.370$)$, grip strength $(0.719$ and 0.670$)$, flexibility $(0.432$ and 0.335$)$, hand-eye coordination (0.546 and 0.539), weight of the limbs (0.887 and 0.855) leg muscle power $(0.765$ and 0.750$)$, agility (0.789 and 0,783$)$, velocity (0.8158 and 0.816$)$ and cardiovascular endurance (0.754 and 0.715 ) will impose FIK UNM students in improving the skill of a drive blow in a squash game.

In order for the results of this study can be utilized to improve the skills of forehand punch in the game of student squad FIK UNM Makassar then put forward the following suggestions; 1) To the teachers / builders of squash, to select the athlete seeds that will be aimed at continuous performance improvement should always pay attention to the anthropometry and physical elements that play a role in determining the skills of the drive blow in squash games, especially weight, height, leg length, strength grip, balance, flexibility, hand eye coordination, leg muscle power, speed, agility and cardiovascular endurance; 2) To the trainer, to develop a proper training program should consider factors that have high and low contribution value to the driving skill in squash game, so that in the process of implementation the guidance can be appropriate and in accordance with the needs of tennis field, and have an impact on improving the quality of skills and achievement of pemian; 3) To the athlete should have a deep individual consideration of the anthropometric and physical 
conditions of each, to foster self-confidence in the field as well as exercise and constantly improve the ability of biomotor to achieve the highest achievement; and 4) To colleagues who will conduct similar research, it is advisable to conduct further research with broader coverage with more samples as well as to see the possibility of other variables that also have a positive relationship with the skills of a drive blow in a squash game.

\section{References}

Bompa, Tudor O. (2009). Theory and Methodology of training, Dubuque, Iowa: Hunt PublishingCompany..

Gallahue, David, L., \&Ozmun, John, C. (1998).Understanding Motor Development: Infants, Childern, Adolencents, Adults"Glass Gene V., Hopkins Kenneth D., Statistical Methods in Educational and Psychology. New Jersey: Englewood Cliff; Prentice Hall, Inc., 1989.

Hanlon Thomas. (2009), The Sports Rules Book. Champaign: Human Kinetics Publisher.

Harsono. 1988. Coaching dan aspek-aspek psikologis dalam coaching. Jakarta. C.V. TambakKusuma,.

http://www.squashfit.org/blog/solo-squash-drills/ (diakses tanggal 15/2/2017

Irianto, Pekik, Djoko.(2002). Dasar Kepelatihan. Yogyakarta: FIK UNY.

Sugiyono. (2010), Metode Penelitian Kuantitatif, Kualitatif dan R\&D. Bandung: Alfabeta

Sajoto, M. (1995) Pembinaan Kekuatan Kondisi Fisik Dalam Olahraga. Semarang: Effhar \& Dahara Prize Offset.

Tangkudung James. (2012), Kepelatihan Olahraga, Pembinaan Prestasi Olahraga. Jakarta: Cerdas Jaya.

Yarrow Philip., Harrison Aidan. (2010), Squash Steps to Success. Champaign: Human Kinetics Publisher Inc. 